\title{
TEORI DAN KONTRIBUSI METODE KISAH QUR'ANI DALAM PENDIDIKAN AGAMA ISLAM DI SEKOLAH
}

\author{
Permana Octofrezi \\ Sekolah Tinggi Agama Islam Masjid Syuhada Yogyakarta \\ E-mail: octofrezi@gmail.com
}

\section{Abstrak}

Peran pendidik dalam mentransfer ilmu memerlukan berbagai macam metode yang efektif dan sesuai dengan iklim peserta didik. Pemilihan metode sangat urgen untuk menentukan output seperti apa yg diinginkan. Dari sekian ragam metode yang diajarkan kepada peserta didik, sebuah metode kisah Qurani mampu memberikan banyak kontribusi kepada Pendidikan Agama Islam (PAI) khususnya di sekolah. Dalam kitab suci Al-Quran banyak sekali terdapat kisah-kisah yang bisa diambil ibroh (pelajaran) berharga bagi peserta didik. Kisah kenabian, kisah orang-orang sholeh, kisah kaum yang terkena adzab, dan lain sebagainya. Selain menarik, metode kisah Qurani membuka wawasan berpikir, rasa keingintahuan yang tinggi akan peristiwa masa lalu yang dapat dijadikan pijakan dalam menapaki kehidupan yang akan datang. Metode kisah Qurani ini juga memiliki kesan tersendiri karena lebih gampang diingat dan diserap dengan baik jika pendidik mampu menyampaikannya sesuai dengan prinsip, strategi dan langkah-langkah yang sesuai. Pendidik bisa mengembangkan prinsip, strategi dan langkah-langkah dalam berkisah tersebut sesuai dengan ide dan kreatifitasnya sendiri. Orisinalitas kisah Qurani yang tidak diragukan lagi kebenarannya bisa menambah khazanah keilmuan, menyuburkan keimanan, dan memotivasi pendengar khususnya peserta didik. Metode kisah Qurani tidak akan usang oleh perkembangan zaman dan kemajuan teknologi sampai manusia itu masih mau mendengarkan, mau belajar dan merubah diri.

Kata Kunci: Teori, Kontribusi, Metode, Kisah Qur'ani.

\section{Abstract}

The role of educators in transferring science requires a variety of methods that are effective and appropriate to the climate of learners. The choice of method is very urgent to determine what the desired output is. Of the various methods taught to learners, a Qurani story method is able to contribute significantly to 
Islamic Religious Education (PAI), especially in schools. In the holy book of the Qur'an there are many stories that can be taken ibroh (lessons) valuable for learners. Prophetic stories, stories of sholeh people, stories of people affected by adzab, and so forth. In addition to the interesting, Qurani story method open the insight of thinking, a sense of high curiosity about past events that can be used as a foothold in tread the life to come. This Quranic story method also has its own impression because it is more easily remembered and absorbed properly if the educator is able to deliver it according to the principles, strategies and steps accordingly. Educators can develop principles, strategies and steps in the story in accordance with the idea and creativity itself. The originality of the Quranic story undoubtedly can add to the treasures of scholarship, cultivate faith, and motivate listeners, especially learners. The Quranic story method will not be obsolete by the times and technological advancements until humans are still willing to listen, to learn and to change themselves.

Keywords: Theory, Contribution, Method, Qur'anic Story.

\section{PENDAHULUAN}

\section{A. Latar Belakang Masalah}

Di dalam kitab suci Al-Quran banyak sekali terdapat kisah-kisah maupun berbagai peristiwa yang dapat dipetik hikmahnya. Sebagai kitab suci paripurna, Alquran memuat beragam petunjuk bagi manusia, salah satunya adalah melalui beraneka kisah peristiwa ataupun cerita-cerita. Suatu peristiwa yang berhubungan dengan sebab dan akibat dapat menarik perhatian para pendengar apabila dalam peristiwa itu terselip pesan-pesan dan pelajaran mengenai peristiwa masa lalu, bahkan peritiwa futuristik (mendatang). Perhatian dari para pendengar pun memunculkan curiosity atau rasa ingin tahu. Inilah yang menjadi landasan paling kuat dalam menanamkan kesan peristiwa tersebut ke dalam hati pendengar (peserta didik). 
Permana Octofrezi : Teori dan Kontribusi Metode Kisah Qur'ani dalam Pendidikan Agama Islam Di Sekolah

Dan nasihat dengan tutur kata yang disampaikan tanpa variasi tidak mampu menarik akal, bahkan semua isinya pun tidak akan bisa dipahami. Akan tetapi bila nasihat itu dituangkan dalam bentuk kisah yang menggambarkan peristiwa dalam realita kehidupan, maka akan terwujudlah dengan jelas tujuannya. Orang pun akan merasa senang mendengarnya, memperhatikannya dengan penuh kerinduan dan rasa ingin tahu, dan pada gilirannya ia akan terpengaruh dengan nasihat dan pelajaran yang terkandung didalamnya. ${ }^{216}$

Dalam Al-Qur'an terdapat berbagai sejarah dan kisah yang pernah terjadi di zaman yang lampau kala manusia belum pandai menuliskan sejarah. Dengan menceritakan kisah semacam ini, Al-Qur'an tidak bermaksud memberikan hiburan atau memberi data sejarah, tetapi mendirikan suatu masyarakat yang berlandaskan ajaran-ajaran yang diberikannya, dan supaya manusia dapat mengambil pelajaran-pelajaran moral dari kehidupan para pendahulu mereka. ${ }^{217}$ Al-Qur'an sebagai kitab terakhir, sebagai penutup segala kitab sebelumnya mempunyai keunggulan yang membuatnya istimewa dibandingkan dengan kitab suci yang lainnya. ${ }^{218}$

Dalam pendidikan islam, kisah tentang kehidupan para nabi, para pejuang, dan para ulama menempati posisi yang tinggi. Karena orang yang membacakan cerita, atau orang yang mendengarkannya, merasa hidup dengan para nabi, para pejuang islam, atau para ulama yang menjadi tokoh cerita.

216 Manha' Khalil al-Qattan, Studi Ilmu-ilmu Qur'an, terj. (Jakarta: Lentera Antar Nusa dan Pustaka Islami, 2000), hlm. 435

217 S.M. Suhufi, Kisah-kisah dalam Al-Qur'an, (Bandung: PT. AlBayan, 1994), hlm. 7

218 TM. Hasbi ash-Shiddieqy, Sejarah dan Pengantar Ilmu Al-Qur'an dan Tafsir, (Jakarta: Bulan Bintang, 1990), hlm. 139 
Dari kisah mereka tersebut, kita dapat memetik ajaran dan tuntunan yang baik yang dapat kita jadikan pegangan dalam kehidupan kita sehari-hari. ${ }^{219}$

Penerapan metode kisah dirasa sangat menyentuh nurani pendengar. Dengan harapan, materi pendidikan agama islam yang dikemas dalam cerita tersebut memberikan kontribusi ilmu yang terserap dengan baik. Metode ini juga efektif di berbagai jenjang usia, sehingga sangat lazim untuk diterapkan sebagai sarana penyampaian ilmu.

\section{B. Rumusan Masalah}

Dari beberapa uraian di atas, maka permasalahan yang terkait dengan penelitian ini dapat diidentifikasikan sebagai berikut:

1. Bagaimana pengertian, manfaat, danmacam-macam Kisah dalam Al-Qur'an?

2. Bagaimana kontribusi metode kisah Qurani dalam Pendidikan Agama Islam di sekolah?

\section{Tujuan dan Kegunaan Penelitian}

Tujuan utama penelitian ini dilakukan untuk mengetahui, membahas dan menganalisa secara sistematis terhadap teori kisah dan nilai-nilai pendidikan kisah dalam AlQur'an.

Apabila tujuan utama tersebut diatas tercapai, maka kegunaan dari penelitian ini adalah sebagai berikut:

1. Dapat memahami pengertian, manfaat dan macam-macam Kisah dalam Al-Qur'an.

2. Dapat mengetahui kontribusi metode kisah Qurani dalam Pendidikan Agama Islam di sekolah.

219 Adil Musthafa Abdul Halim, Kisah Bapak \& Anak dalam Al-Qur'an, (Jakarta : Gema Insani Press, 2007), hlm. 12 
Permana Octofrezi : Teori dan Kontribusi Metode Kisah Qur'ani dalam Pendidikan Agama Islam Di Sekolah

\section{PEMBAHASAN}

\section{A. Pengertian Kisah dalam Al-Qur'an}

Kisah berasal dari bahasa arab yang diambil dari kata al-qassu yang berarti mencari atau mengikuti jejak. Dikatakan, "qashasshtu atsarahu" artinya, "saya mengikuti atau mencari jejaknya." Qasas berarti berita yang berurutan. Sedang AlQissah berarti urusan, berita, perkara dan keadaan. Qasas AlQur'an adalah pemberitaan Al-Qur'an tentang hal ihwal umat yang telah lalu, nubuwat (kenabian) yang terdahulu dan peristiwa-peristiwa yang telah terjadi. Al-Qur'an banyak mengandung keterangan tentang kejadian masa lalu, sejarah bangsa-bangsa, keadaa negeri-negeri dan peninggalan atau jejak setiap umat. Ia menceritakan semua keadaan mereka dengan cara yang menarik dan mempesona. 220

Kata al-qashash adalah bentuk masdar. 221 Seperti firman Allah yang artinya :

قال (berkata): Musa - ذلك (itulah) tempat kita kehilangan ikan itu - ما (tempat) sesuatu - كنانب (yang kita cari") kita caricari, karena sesungguhnya hal itu merupakan pertanda bagi kita bahwa kita akan dapat bertemu dengan orang yang sedang kita cari. - فارتدا (lalu keduanya kembali) kembali lagi قصصا - عengikuti jejak mereka semula) menitinya) على اثارهما (secara benar-benar) lalu keduanya sampai di batu besar tempat mereka beristirahat. ${ }^{222}$

Kata yang berasal dari bahasa arab tersebut diserap ke dalam bahasa Indonesia menjadi "Kisah" yang berarti cerita.

220 Syaikh Manna Al-Qathathan, Pengantar Studi Ilmu Al-Qur'an, (Jakarta: Pustaka Al-Kautsar, 2006), hlm. 387.

221 Ibid, hlm. 387.

222 Imam Jalaluddin Al-Mahalli dan Imam Jalaluddin As-Suyuti, Tafsir Jalalain berikut asbabun nuzul ayat Jilid 2, (Bandung: Sinar Baru Algesindo, 2013), hlm. 27 
Namun terdapat perbedaan prinsipil antara makna kisah dalam bahasa Al-quran dengan kisah dalam bahasa Indonesia. Kisah dalam bahasa al-quran bermakna sejarah (tarikh) yaitu peristiwa-peristiwa yang pernah terjadi di zaman dahulu. Sedangkan kisah dalam bahasa Indonesia mengandung arrti cerita-cerita yang berbau mistik atau legenda yang di dalam AlQuran disebut "Ashatir". Kata "Qashah" dengan berbagai bentuknya dimuat pada 30 ayat dalam Al-Quran yang bertebaran pada berbagai surat, diantaranya Allah berfirman:

"lalu kedua orang itu kembali lagi untuk mengikuti jejak darimana keduanya itu datang (Q.S. Al-kahfi (18) : 64)

Dan firman Allah melalui lisan Ibu Musa:

"Dan berkatalah ibu Musa kepada saudara Musa yang perempuan : "ikutilah dia" maka kelihatanlah olehnya Musa dari jauh, sedang mereka tidak mengetahuinya” (Q.S. AlQashash (28) : 11)

Maksudnya dari ayat diatas adalah ikutilah jejaknya, sampai kamu melihat siapa yang mengambilnya. ${ }^{223}$

Kisah-kisah dalam Al-Qur'an menyikapi beberapa peristiwa baik yang telah terjadi sebelum Al-Qur'an atau peristiwa-peristiwa yang akan terjadi. Dalam sebuah kisah paling tidak ada 4 hal yang terdapat di dalamnya yaitu : Pertama jenis peristiwa itu sendiri, kedua pelaku peristiwa, ketiga tempat peristiwa, keempat waktu peristiwa. ${ }^{224}$ Sebuah kisah paling tidak memuat empat hal yaitu, pertama jenis peristiwa kedua, pelaku peristiwa, ketiga, tempat peristiwa, keempat, pelaku peristiwa. Jadi suatu peristiwa bisa

223 Syahidin, Menelusuri Metode Pendidikan dalam Al-Quran, (Bandung : Alfabeta, 2009), hlm. 93-94.

224 Ahmad Syadzali, et.al., Ulumul Qur'an II, (Bandung: Pustaka Setia, 1997), Cet. I, hlm. 31 
Permana Octofrezi : Teori dan Kontribusi Metode Kisah Qur'ani dalam Pendidikan Agama Islam Di Sekolah

digolongkan sebagai kisah apabila mencakup empat hal tersebut. Al-Qur'an menceritakan beberapa kejadian masa lalu, tentang umat-umat terdahulu dan syari'at-syari'atnya yang terhapus, orang-orang sekarang hampir tidak ada yang mengetahui kisah-kisah tersebut, kecuali hanya sebagian kecil ahli kitab yang mempelajarinya. Kisah yang ditampilkan AlQur'an disampaikan secara global dan terperinci dalam serial yang antara satu dengan seri yang lainnya saling berkaitan. ${ }^{225}$

Kisah dalam Al-Quran merupakan peristiwa yang benar-benar terjadi pada manusia-manusia terdahulu dan merupakan peristiwa sejarah yang dapat dibuktikan kebenarannya secara filosofis dan secara ilmiah melalui saksisaksi bisu berupa peninggalan-peninggalan orang-orang terdahulu seperti Ka'bah di Makkah, Masjidil Aqsha di Palestina, Piramida dan Spink di Mesir dan sebagaianya. Bukan saja peristiwa masa laul naun juga peristiwa yang bakal terjadi di masa yang akan datang, seperti peristiwa yang akan terjadi di akhirat. 226

\section{B. Manfaat Kisah Qurani}

Berikut manfaat yang diperoleh dari kisah-kisah AlQuran dalam menanamkan nilai-nilai pendidikan adalah sebagai berikut:227

1. Menjelaskan asas-asas dakwah islam menuju Allah dan dapat menjelaskan pokok-pokok syari'at yang dibawa oleh para nabi.

225 Sayyid Muhammad Alwi al-Maliki, Keistimewaan-keistimewaan AlQur'an, terj. Nur Faizin, (Yogyakarta: Mitra Pustaka, cet. I, 2001), hlm. 46 226 Syahidin, Menelusuri Metode Pendidikan dalam Al-Quran,... hlm. 95.

227 Ibid, hlm. 98-99. 
2. Untuk meneguhkan hati rasulullah dan hati ummat Muhammaad atas aagamaa Allah, memperkuat kepercayaan orang mukmin tentang menangnya kebenaran dan para pendukungnya serta hancurnya kebathilan dan para pembelanya.

3. Membenarkan para nabi terdahulu, menghidupkan kenangan terhadap mereka serta mengabadikan jejak dan peninggalnnya baik berupa benda maupun berupa syari'atnya seperti jejak dan syari'at nabi Ibrahim tentang Qurban.

4. Menampakkan kebenaran Muahammad SAW dalam dakwahnya dengan apa yang diberitakannya tentang hal ihwal orang-orang terdahulu di sepanjang kurun dan generasi.

5. Menyimak kebohongan ahli kitab dengan hujjah yang membeberkan keterangan dan petunjuk yang mereka sembunyikan. Dan menantang mereka dengan sisi kitab mereka sendiri sebelum kitab itu dirubah dan diganti.

6. Kisah termasuk salah satu bentuk sastra yang dapat menarik perhatian para pendengar dan banyak mengandung pelajaran guna memantaapkan pesan-pesan yang dikandungnya ke dalam jiwa.

\section{Macam-macam Kisah dalam Al-Qur'an}

Kisah dalam Al-Qur'an dikelompokkan menjadi beberapa macam. klasifikasi dari segi waktu dan klasifikasi dari segi materi. 228

228 Syaikh Manna Al-Qathathan, ... (Jakarta: Pustaka Al-Kautsar, 2006), hlm. 388. 
Permana Octofrezi : Teori dan Kontribusi Metode Kisah Qur'ani dalam Pendidikan Agama Islam Di Sekolah

Pertama : Klasifikasi ditinjau dari segi Waktu. Ditinjau dari segi waktu, kisah-kisah dalam Al-Qur'an ada tiga tahap, yaitu :

1. Kisah hal gaib yang terjadi pada masa lalu. Contohnya kisah tentang dialog malaikat dengan Tuhannya mengenai penciptaan khalifah di muka bumi.

2. Kisah gaib yang terjadi pada masa kini. Contohnya kisah tentang turunnya malaikat-malaikat pada malam lailatul qadar.

3. Kisah hal gaib yang akan terjadi pada masa yang akan datang. Contohnya kisah tentang Abu Lahab kelak di akhirat.

Kedua : Klasifikasi ditinjau dari segi Materi. Ditinjau dari segi materi kisah kisah dalam Al-Qur'an ada tiga tahap, yaitu :

\section{Kisah Para Nabi}

Kisah ini mengandung dakwah mereka kepada kaumnya, mukjizat-mukjizat yang memperkuat dakwahnya, sikapsikap orang-orang yang memusuhinya, tahapan-tahapan dakwah dan perkembangannya serta akibat-akibat yang diterima oleh mereka yang mempercayai dan golongan yang mendustakan. Misalnya kisah Nuh, Ibrahim, Musa, Harus, Isa, Muhammad dan nabi-nabi serta rasul lainnya

2. Kisah-kisah yang berhubungan dengan peristiwa-peristiwa yang terjadi pada masa lalu dan orang-orang yang tidak dipastikan kenabiannya. Misalnya orang yang keluar dari kampung halaman, yang beribu-ribu jumlahnya karena takut mati, kisah Talut dan Jalut, dua orang putra adam, penghuni gua, zulkarnain, orang-orang yang menangkap 
Permana Octofrezi : Teori dan Kontribusi Metode Kisah Qur'ani dalam Pendidikan Agama Islam Di Sekolah

ikan pada hari Sabtu, Maryam, Ashabul Ukhdud, Ashabul Fiil dan lain-lain

3. Kisah-kisah yang berhubungan dengan peristiwa-peristiwa yang terjadi pada masa Rasulullah, seperti perang Badar dan perang Uhud dalam surah Ali Imran, perang Hunain dan Tabuk dalam surat At-Taubah, perang Ahzab dalam surat Al-Ahzab, Hijrah, Isra Mi'raj, dan lain-lain.229

\section{Kontribusi Metode Kisah Qurani dalam Pendidikan Agama Islam di Sekolah}

Metode kisah yang diterapkan dalam menyampaikan pelajaran PAI di sekolah amatlah berkesan dan menyenangkan siswa. Mulai dari jenjang pendidikan dasar sampai menengah ke atas (SMA). Guru bisa menyampaikan nasehat tanpa terkesan menggurui atau mendikte siswanya. Terutama terhadap siswa yang kebal dengan nasehat secara langsung. Kisah-kisah dalam Alquran memiliki fungsi edukatif yang sangat berharga dalam suatu proses penanaman nilai-nilai ajaran islam.

Dalam upaya menerapkan metode kisah ini dalam pendidikan agama islam di sekolah, perlu diperhatikan prinsip-prinsip dan langkah-langkah dalam perencanaan, pelaksanaan maupun evaluasinya. Langkah-langkah ini dapat dikembangkan sendiri oleh gurunya sesuai dengan ide dan kreatifitas masing-masing, karena setiap guru memiliki kelebihan dan keunikannya masing-masing.

Adapun kontribusi metode Kisah Qurani dalam Pendidikan Agama Islam (PAI) antara lain dalam aspek: dampak pelaksanaan metode, prinsip dan strategi, langkah-

229 Manha' Khalil al-Qattan, Studi Ilmu-ilmu Qur'an, terj. (Jakarta: Lentera Antar Nusa dan Pustaka Islami, 2000), hlm. 436. 
Permana Octofrezi : Teori dan Kontribusi Metode Kisah Qur'ani dalam Pendidikan Agama Islam Di Sekolah

langkah pelaksanaan, serta contoh-contoh kisah Qurani yang relevan dengan Pendidikan Agama Islam. Aspek tersebut akan diterangkan di bawah ini:

1. Dampak Kisah Qurani

Bercerita atau berkisah juga memiliki dampak bagi para siswa. Banyak sekali bahan yang dapat kita berikan kepada siswa, misal cerita berhikmah (kisah nyata), kisah nabi dan rosul, kisah sahabat, dan lain sebagainya. Dalam pendidikan Islam, kisah tentang kehidupan para nabi, para pejuang, dan para ulama menempati posisi yang tinggi. Karena orang yang membacakan cerita, atau orang yang mendengarkannya, merasa hidup dengan para nabi, para pejuang Islam, atau para ulama yang menjadi tokoh cerita.

Dari kisah mereka tersebut, kita dapat memetik ajaran dan tuntunan yang baik yang dapat kita jadikan pegangan dalam kehidupan kita sehari-hari. Dapat pula kita jadikan landasan etika bergaul kita dengan keluarga kita, saudara-saudara kita, para kerabat kita, serta dengan semua manusia, baik dengan orang muslim ataupun orang non muslim. 230

Kisah Qurani membawa dampak yang positif secara langsung terhadap kejiwaan siswa. Di antara dampaknya adalah :231

a. Dampak terhadap emosi murid :

1) Tertanamnya kebencian terhadap kedzaliman dan kecintaan terhadap kebajikan

2) Tertanamnya rasa takut akan siksa Allah dan tumbuhnya harapan terhadap rahmat Allah

230 Adil Musthafa Abdul Halim ,.. (Depok : Gema Insani Press, 2007), 231 Ibid, hlm. 100-101. 
Permana Octofrezi : Teori dan Kontribusi Metode Kisah Qur'ani dalam Pendidikan Agama Islam Di Sekolah

b. Dampak terhadap motivasi murid :

1) Memperkuat rasa percaya diri dan kebanggaan terhadap ajaran agamanya

2) Menumbuhkan keberanian, mempertahankan kebenaran, dan meningkatkan rasa keingintahuan.

c. Dampak terhadap penghayatan murid :

1) Timbulnya kesadaran melaksanakan perintah agama

2) Timbulnya rasa keikhlasan, kesabaran dan tawakal

d. Dampak terhadap pola pikir murid ;

1) Melatih berfikir kritis

2) Melatih berfikir realistis

3) Melatih berfikir analitis

4) Melatih berfikir analogis

2. Prinsip dan Strategi penerapan metode kisah

Jika kisah dalam Al-Quran dijadikan sebagai bahan pelajaran, maka kisah tersebut harus disajikan secara utuh. Sebagaimana kisah nabi saat ini sudah dimasukkan ke dalam materi pelajaran Pendidikan Agama Islam (PAI) mulai dari tingkatan SD sampai SMA. Namun, jika kisah itu dijadikan metode mengajar, maka tidak perlu disajikan secara utuh cukup penggalan-penggalannya saja. Penggalan-penggalan kisah itu dapat dijadikan sebagai alat untuk membawa murid pada suatu pemikiran atau kejiwaan tertentu dalam rangka memancing perhatian dan perasaan murid.

Adapun strategi penerapan metode kisah ini adalah sebagai berikut :232

232 Ibid, hlm. 104-105. 
Permana Octofrezi : Teori dan Kontribusi Metode Kisah Qur'ani dalam Pendidikan Agama Islam Di Sekolah

a. Penggalan kisah dijadikan pengantar untuk membawa murid pada suatu pemikiran, penghayatan terhadap nilai-nilai tertentu.

b. Penggalan-penggalan kisah Qurani dapat dijadikan sebagai materi pokok dalam topik bahasan yang disampaikan. Suatu kisah dalam AlQuran tidak disampaikan secara utuh namun diambil bagian-bagian tertentu saja sesuai dengan kebutuhan dari bahan pelajaran.

c. Penggalan kisah dapat dijadikan alat untuk memancing perhatian murid terhadap materi pelajaran yang akan disampaikan

d. Penggalan kisah dijadikan alat untuk memancing emosi sehingga muncul keberanian untuk membela kebenaran murid

e. Penggalan kisah dijadikan sebagai alat untuk menanamkan kebencian terhadap perbuatan munkar dan kecintaan terhadap kebajikan.

f. Potongan kisah dijadikan alat untuk memancing rasa ingin tahu murid sehingga muncul motivasi untuk mengetahui kisah tersebut secara lengkap. Hal ini dilakukan untuk merangsang murid agar gemar membaca.

g. Potongan kisah dapat dijadikan sebagai titik kulminasi penghayatan murid terhadap penanaman suatu nilainilai tertentu seperti menumbuhkan keberanian, kejujuran, keikhlasan, kesabaran dan sebagainya. ${ }^{233}$

233 Ibid, hlm. 98-99. 
3. Langkah-langkah penggunaan metode kisah

Berikut ini langkah-langkah yang dapat ditempuh oleh Guru dalam menyajikan bahan pelajaran yang berkenaan dengan materi Pendidikan Agama Islam dalam rahah akdh dan akhlak dengan menggunakan metode kisah yaitu sebagaia berikut :234

a. Langkah Persiapan.

1) Guru mempersiapkan pokok bahasan dan sub pokok bahasan darui suatu mata pelajaran tertentu secara utuh

2) Mengumpulkan penggalan-penggalan kisah Qurani yang berhubungan dengan sub pokok bahasan.

3) Menyusun tokoh-tokoh dalam kisah tersebut untuk diingat dan dihafal murid

4) Menyusun pertanyaaan-pertanyaan

b. Langkah Pelaksanaan

1) Guru menyebutkan tema pokok pelajaran dan kisah Qurani yang akan disajikannya guna menarik perhatian dan konsentrasi murid.

2) Kisah-kisah Qurani yang disajikan dianalogikan dengan pengalaman-pengalaman praktis murid dalam kehidupan sehari-harinya

3) Dalam penyampaian materinya, geraakan badan, mimik muka harus turut mendukung pada penyampaian terutama pada penegasan inti pelajaran.

4) Materi pokok pelajaran disampaikan disaat klimaks dari suatu penggalan kisah 
Permana Octofrezi : Teori dan Kontribusi Metode Kisah Qur'ani dalam Pendidikan Agama Islam Di Sekolah

c. Langkah Evaluasi

1) Guru mengajukan pertanyaan-pertanyaan yang telah disusun di rumah

2) Guru menanyakan tokoh-tokoh dalam kisah yang telah disajikan

3) Guru menegaskan kembali inti dari pokok pelajaran

4) Guru menugaskan untuk membaca dan membuka kembali kelengkapan kisah yang telah disajikan.

\section{E. Contoh kisah - kisah dalam Al-Quran dan relevansinya} dalam Pendidikan Agama Islam

Isi dari cerita-cerita dalam Al-Quran merupakan bahan pelajaran dalam Pendidikan Agama Islam, di dalamnya terkandung berbagai informasi tentang peritiwa sejarah baik mengenai kehidupan para nabi, orang-orang shaleh, orangorang yang durhaka dan peristiwa - peristiwa lainnya yang berkenaan dengan sejarah dan perkembangan hidup manusia, yang sangat penting untuk diketahui khususnya oleh para pelajar.

Beberapa contoh kisah tersebut antara lain: 235

1. Kisah Peristiwa penciptaan nabi Adam as pertama, dimuat pada Q.S. Al-Baqarah (2) ayat 30-39, kemudian pada surat Al-Hijr (15) ayat 28-40

2. Kisah nabi Ibrahim as. mencari Tuhan dimuat pada Q.S. Al-An'am (6) : 74-79,

3. Kisah tentang dialog ketuhanan Ibrahim dengan kaumnya dan orangtuanya dimuat pada Q.S. Al-Anbiya (21) ayat 5167, Q.S. Maryam (19) : 41-54, As-Shoffat (37) : 101-111, dsb.

235 Ibid, hlm. 98-99. Syahidin, Menelusuri Metode Pendidikan dalam Al-Quran,... hlm. 108. 
4. Kisah Nabi Musa As. Dimuat dalam Q.S. Al-Qashash (28) ayat 7-35, Q.S. Toha (20), ayat 57-73, dan 85 - 97, Q.S. AlMaidah (5) ayat $21-26$, dsb.

5. Kisah Orang Sholeh seperti Lukman Al-Hakim dimuat dalam Surat Luqman (31), ayat 12-19.

6. Kisah orang yang dzolim seperti Qorun dimuat dalam Q.S. Al-Qashash (28) ayat $76-82$, dsb.

7. Kisah seorang Rosul yang sangat rinci dan dimuat dalam sebuat surat secara khusus yaitu tentang cerita nabi Yusuf As. Hampir seluruh ayat dalam surat Yusuf As menceritakan tentang perjalanan sejarah nabi Yusuf As, yakni mulai ayat 4 sampai denggan 101. Begitu juga dengan kisah nabi Muhammad SAW juga dimuat dalam surat Muhammad. Lain halnya dengan Surat Ibrahim, sekalipun surat itu dinamai Surat Ibrahim sebagai pelaku sejarah dalam Al-Quran, namun di dalamnya tidak banyak menceritakan tentang kehidupan nabi Ibrahim as.

\section{PENUTUP}

Kisah berasal dari kata al-qashshu yang berarti mencari atau mengikuti jejak. Dikatakan, "qashasshtu atsarahu" artinya, "saya mengikuti atau mencari jejaknya."

Kisah dalam Al-Qur'an diklasisfikasikan menjadi dua macam. Pertama: dari segi waktu, pertama; kisah hal gaib yang terjadi pada masa lalu, kedua; kisah hal gaib yang terjadi pada masa Rasulullah, ketiga; kisah hal gaib yang akan terjadi dimasa yang akan datang. Kedua: dari segi materi, pertama; kisah para nabi, kedua; kisah-kisah yang berhubungan dengan peristiwa-peristiwa yang terjadi pada masa lalu dan orang-orang yang tidak dipastikan kenabiannya, ketiga; Kisah- 
Permana Octofrezi : Teori dan Kontribusi Metode Kisah Qur'ani dalam Pendidikan Agama Islam Di Sekolah

kisah yang berhubungan dengan peristiwa-peristiwa yang terjadi pada masa Rasulullah.

Kontribusi metode Kisah Qurani dalam Pendidikan Agama Islam (PAI) antara lain dalam aspek: dampak pelaksanaan metode, prinsip dan strategi, langkah-langkah pelaksanaan, serta contoh-contoh kisah Qurani yang relevan dengan Pendidikan Agama Islam. 


\section{DAFTAR PUSTAKA}

Adil Musthafa Abdul Halim, 2007, Kisah Bapak \& Anak dalam AlQuran, Jakarta: Gema Insani Press.

Ahmad Syadzali, et.al., 1997, Ulumul Qur'an II, Bandung: Pustaka Setia.

Imam Jalaluddin Al-Mahalli dan Imam Jalaluddin As-Suyuti, 2013, Tafsir Jalalain berikut asbabun nuzul ayat Jilid 2, Bandung: Sinar Baru Algesindo.

Manha' Khalil Al-Qattan, 2000, Studi Ilmu-ilmu Qur'an, terj. Jakarta: Lentera Antar Nusa dan Pustaka Islami.

Sayyid Muhammad Alwi al-Maliki, 2001, Keistimewaankeistimewaan Al-Qur'an, terj. Nur Faizin, Yogyakarta: Mitra Pustaka, cet. I.

S.M. Suhufi, 1994, Kisah-kisah dalam Al-Qur'an, Bandung: PT. AlBayan.

Syahidin, 2009, Menelusuri Metode Pendidikan dalam Al-Quran, Bandung: Alfabeta.

Syaikh Manna Al-Qathathan, 2006, Pengantar Studi Ilmu AlQur'an, Jakarta: Pustaka Al-Kautsar.

TM. Hasbi ash-Shiddieqy, 1990, Sejarah dan Pengantar Imu AlQur'an dan Tafsir, Jakarta: Bulan Bintang. 